\title{
Pengaruh Dosis Injeksi Antemortem Papain Kasar terhadap Kualitas Fisik dan Organoleptik Daging Ayam Petelur Afkir pada Jenis Otot yang Berbeda
}

\author{
Agustin Widiastuti, Pudjomartatmo dan Adi Magna Patriadi Nuhriawangsa \\ Program Studi Peternakan, Fakultas Pertanian, Universitas Sebelas Maret \\ Jl. Ir. Sutami 36A, Kentingan, Jebres, Surakarta 57126
}

\begin{abstract}
ABSTRAK
Penelitian bertujuan untuk mengetahui pengaruh dosis injeksi antemortem papain kasar, jenis otot dan interaksinya terhadap kualitas fisik dan organoleptik daging ayam petelur afkir. Sampel menggunakan daging dada dan paha ayam petelur afkir umur 82 minggu sebanyak 20 ekor. Rancangan Acak Lengkap menggunakan Pola Faktorial 4x2. Faktor A terdiri dari $\mathrm{A}_{1}$ : tanpa dosis papain (kontrol); $\mathrm{A}_{2}$ : dosis papain $1 \mathrm{mg} / \mathrm{kg} \mathrm{BB} ; \mathrm{A}_{3}$ : dosis papain $2 \mathrm{mg} / \mathrm{kg}$ BB dan $\mathrm{A}_{4}$ : dosis papain 3 $\mathrm{mg} / \mathrm{kg} \mathrm{BB}$, faktor $\mathrm{B}$ terdiri dari $\mathrm{B}_{1}$ : dada dan $\mathrm{B}_{2}$ : paha. Data dianalisis menggunakan Analysis of Variance dan dilanjutkan dengan Duncan's Multiple Range Test. Pemberian dosis papain kasar memberikan pengaruh yang sangat nyata $(\mathrm{P}<0,01)$ terhadap semua parameter kecuali kekuatan tarik $(\mathrm{P}<0,05)$. Bagian tubuh memberikan pengaruh sangat nyata $(\mathrm{P}<0,01)$ terhadap keempukan, kekuatan tarik, DIA, susut masak, organoleptik (keempukan, tekstur dan jus) dan kesukaan $(\mathrm{P}<0,05)$. Terdapat interaksi antara pemberian dosis papain kasar dan bagian tubuh terhadap DIA, organoleptik dan hedonik $(\mathrm{P}<0,01)$, susut masak $(\mathrm{P}<0,05)$. Dosis injeksi papain $3 \mathrm{mg} / \mathrm{kg} \mathrm{BB}$ pada daging paha dan dada mempunyai kualitas fisik terbaik dan injeksi papain $3 \mathrm{mg} / \mathrm{kg}$ BB pada daging dada dan $2 \mathrm{mg} / \mathrm{kg}$ BB pada daging paha mempunyai kualitas organoleptik terbaik.
\end{abstract}

Kata kunci: injeksi antemortem, papain kasar, kualitas fisik dan organoleptik, daging petelur afkir

\section{The Effect of Antemortem Injection Dose of Crude Papain on Physical and Organoleptic Qualities of Post Production Laying Hen Meat in Different Muscle Parts}

\begin{abstract}
The research was aimed to observe the effect of antemortem injection dose of crude papain, muscle part and its interaction on physical and organoleptic qualities post production laying hen meat. The sample used were the breast and thighs from 20 hens on average age 82 weeks. Completely Randomized Design (CRD) used Factorial Pattern $4 \times$ 2. Factor A consisted A1: without papain (control); A2: $1 \mathrm{mg}$ papain/ $\mathrm{kg} \mathrm{BW}$; A3: $2 \mathrm{mg}$ papain/ $\mathrm{kg} \mathrm{BW}$ and A4: $3 \mathrm{mg}$ papain/ $\mathrm{kg} \mathrm{BW}$, factor $B$ consisted B1: breast muscle and B2: thigh muscle. The datas were analyzed by Analysis of Variance and continued by Duncan's Multiple Range Test. The results showed that injection of crude papain dose gave highly significant difference $(P<0.01)$ to all variables except tensile strength $(P<0.05)$. Body parts gave highly significant difference $(P<0.01)$ on shear force, tensile strength, WHC, cooking loss, organoleptic (shear force, texture and juice), and hedonic $(P<0.05)$. The interaction was found between injection of crude papain dose and body part on WHC, organoleptic and hedonic $(P<0.01)$, cooking loss $(P<0.05)$. Dose of $3 \mathrm{mg} / \mathrm{kg} W B$ in thigh and breast meat has the best quality and the organoleptic quality of the combination of papain injection of $3 \mathrm{mg} / \mathrm{kg} \mathrm{WB}$ in breast meat and $2 \mathrm{mg} / \mathrm{kg}$ WB in thigh meat has the best quality.
\end{abstract}

Keywords: antemortem injection, crude papain, physical and organoleptic quality, post production laying hen meat 


\section{PENDAHULUAN}

Permintaan konsumsi daging ayam untuk kebutuhan pangan terus meningkat (Bintoro et al., 2006). Ayam petelur afkir dimanfaatkan dagingnya sebagai pengganti ayam potong (Junaidi, 2009). Daging ayam petelur afkir memiliki kelemahan keras (alot) karena berumur tua sehingga konsumen kurang menyukainya. Umur ternak ikut menentukan kealotan daging karena ikatan-ikatan silang serabut secara individual meningkat sesuai dengan peningkatan umur (Soeparno, 2005).

Jenis otot yang berbeda pada karkas menentukan kualitas yang berbeda, otot dada mempunyai kandungan lemak rendah dan protein tinggi (Nuhriawangsa, 1994), serabut daging seragam dan warna terang (Sutaryo et al., 2006), bagian karkas yang paling dominan dan mempunyai nilai keempukan lebih baik dibanding otot paha pada ayam (Soeparno, 2005). Daging paha mempunyai kualitas keempukan lebih rendah dibanding daging dada karena mempunyai kandungan protein struktural lebih tinggi.

Pengempukan daging dilakukan dengan cara injeksi papain secara antemortem sebelum pemotongan. Papain adalah protease yang diambil dari getah Carica papaya L. (Deulgaonkar et al., 2008). Papain kasar juga mengandung enzim lain, seperti khimopapain dan lisozim (Salman dan Fifi, 2009). Papain dapat menghidrolisis jaringan konektif dan miofibrilair daging yang dapat meningkatkan nilai keempukan daging (Ha et al., 2012).

Berdasarkan uraian di atas maka perlu dilakukan penelitian yang bertujuan untuk mengetahui pengaruh dosis papain kasar dan jenis otot terhadap kualitas fisik dan organoleptik daging ayam petelur afkir dan mengetahui interaksinya.

\section{MATERI DAN METODE}

Bahan yang digunakan ayam petelur afkir strain Lohmann umur 82 minggu dengan berat $1,90 \pm 0,08 \mathrm{~kg}$ sebanyak 20 ekor (Tri Hanggono Rejeki Farm Mojorejo), papain kasar (buah pepaya Thailand umur 1,5 - 2 bulan, petani pepaya Ibu Tatik Tohudan, Colomadu, Karanganyar), Paya (produksi CV. Chem-Mix Pratama, Bantul, Yogyakarta). Alat yang digunakan jarum suntik $1 \mathrm{ml}$, pisau, gunting, timbangan analitik merek Chamry kapasitas $5 \mathrm{~kg}$, waterbath, bakteri-micron Seitz 0,22 $\mu \mathrm{m}$, lemari pendingin, oven, esikator, Liyod instrument, plat kaca, pemberat $35 \mathrm{~kg}$, panelis, piring, plastik PP (poly propilene), kertas saring dan alat tusuk.

Prapenelitian dilaksanakan untuk mengetahui aktivitas papain kasar hasil seleksi dan papain komersial merk Paya. Aktivitas enzim diuji dengan metode menurut CV. Chem-Mix Pratama. Penyadapan getah pepaya menggunakan metode Rukmana (2005), penyiapan bahan injeksi menggunakan metode Huffman et al. (1967) dengan kandungan 1 cc mengandung 10 mg papain kasar (papain kasar sebanyak $1000 \mathrm{mg}$ dalam aquabides steril 100 mililiter, ditambah $\mathrm{NH}_{4} \mathrm{OH}$ untuk buffer penstabil aktifitas enzim sampai $\mathrm{pH}$ 7,3 dan dilakukan penyaringan bakteri-micron Seitz), dilakukan pengistirahatan selama 12 jam sebelum penyuntikan dan penyembelihan (Soeparno, 2005), injeksi papain melalui pembuluh darah pada vena sayap (vena cephalica) sesuai dengan berat badan (Huffman et al., 1967) dan pemotongan setelah 30 menit injeksi (Kang et al., 1974) secara Islami (Nuhriawangsa, 1999).

Proses karkasing, pemotongan dada dan paha serta deboning untuk memperoleh daging dada dan paha menggunakan metode menurut Soeparno (2005). Preparasi sampel untuk uji keempukan, kekuatan tarik, DIA, susut masak menggunakan daging dada. Preparasi sampel untuk uji organoleptik (keempukan, tekstur, jus) dan uji hedonik menggunakan daging paha. Uji keempukan menggunakan Lioyd instrument dengan satuan Newton (Murtini dan Qomarudin, 2003), kekuatan tarik menggunakan Lioyd instrument dengan satuan Newton (Person and Dutson, 1994), daya ikat air (DIA) dengan metode Hamm (Abustam, 2009), 
susut masak menggunakan metode menurut Soeparno (2005), uji organoleptik dan hedonik menggunakan metode menurut Kartika et al. (1988). Uji organoleptik dan hedonik menggunakan panelis yang berjumlah 10 orang dengan skor penilaian keempukan: 1 = alot, 2 = agak empuk, 3 = empuk, 4 = sangat empuk; tekstur: 1 = kasar, 2 = agak lembut, 3 = lembut, $4=$ sangat lembut; juisi: 1 = kering, 2 = agak juici, 3 = juici, $4=$ sangat juici dan uji hedonik (kesukaan): 1 = tidak suka, 2 = kurang suka, 3 = suka, 4 = sangat suka (Kartika et al., 1988).

Penelitian menggunakan Rancangan Acak Lengkap (RAL) Pola Faktorial 4x2 dan jika terdapat perbedaan rerata dilanjutkan dengan Duncan's New Multiple Range Test/DMRT (Hanafiah, 2004). Faktor pertama dosis papain (A) 0, 1, 2, dan 3 $\mathrm{mg} / \mathrm{kg}$ BB dan faktor kedua jenis otot (B) dada dan paha. Setiap aras perlakuan menggunakan lima ulangan.

\section{HASIL DAN PEMBAHASAN}

\section{Aktifitas Enzim}

Hasil uji aktifitas papain kasar yang terdiri dari papain segar dan papain komersial merk Paya disajikan dalam Tabel 1.

Keberadaan protease dinyatakan dengan tingginya aktifitas proteolitik (Siswanto et al., 2009). Besarnya aktifitas protease ditentukan berdasarkan jumlah asam amino yang dihidrolisis dari kasein secara spektrofotometer pada panjang gelombang $570 \mathrm{~nm}$. Aktifitas papain dihitung berdasarkan kurva standar asam amino lisin $\left(\mathrm{Y}=0,0087+7,005 \mathrm{X}, \mathrm{R}^{2}=0,998\right)$. Papain segar mempunyai aktifitas yang lebih tinggi dibanding enzim papain komersial merk Paya, yaitu 21,15 mg/50 mg enzim/jam yang berarti sebanyak $50 \mathrm{mg}$ enzim papain mampu menghidrolisis sebanyak 21,15 mg asam amino dalam waktu satu jam. Paya mempunyai aktifitas enzim sebesar 6,01 $\mathrm{mg} / 50 \mathrm{mg}$ enzim/jam yang berarti sebanyak $50 \mathrm{mg}$ enzim papain mampu menghidrolisis sebanyak 6,01 mg asam amino dalam waktu satu jam.

Aktivitas enzim dipengaruhi oleh suhu, pada kondisi suhu diatas suhu optimum dapat menurunkan aktivitas enzim (Filzahazny, 2009). Proses pengeringan dapat mempengaruhi aktivitas kinetik enzim, pengaruh dapat bersifat dapat balik atau tidak dapat balik. Pada kondisi tidak dapat balik dapat menurunkan aktivitas enzim (Perdana et al., 2012). Paya merupakan produk enzim dalam bentuk serbuk yang mengalami proses pengeringan, sehingga aktivitasnya lebih rendah dibanding papain segar yang akan digunakan dalam penelitian ini.

\section{Kualitas Fisik Daging}

Hasil perhitungan terhadap kualitas fisik daging ayam petelur afkir dengan dosis injeksi papain kasar 0, 1, 2 dan 3 mg/kg BB pada jenis otot dada dan paha disajikan pada Tabel 1.

Dosis injeksi meningkat semakin menurunkan nilai keempukan dan daya tusuk daging. Nilai daya tusuk dan keempukan menurun menunjukan peningkatan keempukan daging (Soeparno, 2005; Tambunan, 2009). Tingkat keempukan daging ditentukan oleh banyak sedikitnya protein jaringan ikat, yaitu kolagen, miofibril, aktomiosin dan elastin (Lawrie, 2003). Protease dari tanaman biduri dapat meningkatkan keempukan daging (Murtini dan Qomarudin, 2003), karena protein jaringan ikat terhidrolisis oleh enzim tersebut menjadi fragmen yang lebih pendek, sehingga menjadi empuk (Ha et al., 2012). Hidrolisis tersebut juga dapat meningkatkan daya ikat air, karena protein miofibril dapat bersifat sebagai basa kuat yang mengikat air (Soeparno, 2005) atau bersifat hidrofilik (Nelson dan Cox, 2000). Hidrolisis tersebut bersifat dapat balik, sehingga protein miofibril mengikat air dan DIA meningkat. Protein kolagen terhidrolisis oleh protease dan membuat fragmen pada bagian mikrostruktur daging (Soeparno, 2005), kondisi ini menyebabkan air dalam daging mengisi fragmen tersebut, sehingga dapat 
Tabel 1. Hasil Analisis Uji Aktifitas (mg/50 mg enzim/jam) Papain Kasar dan Paya

\begin{tabular}{lc}
\hline Jenis Sampel & Aktivitas enzim (mg/50mg/jam) \\
\hline Papain Segar & $21,15^{\mathrm{a}}$ \\
Paya & $6,01^{\mathrm{b}}$ \\
\hline
\end{tabular}

Keterangan: ${ }^{\mathrm{a}, \mathrm{b}}$ Superskrip yang berbeda menunjukkan perbedaan yang nyata $(\mathrm{P}<0,01)$

Tabel 2. Hasil Analisis Kualitas Fisik Daging Ayam Petelur Afkir dengan Dosis Injeksi Papain Kasar pada Jenis Otot yang Berbeda

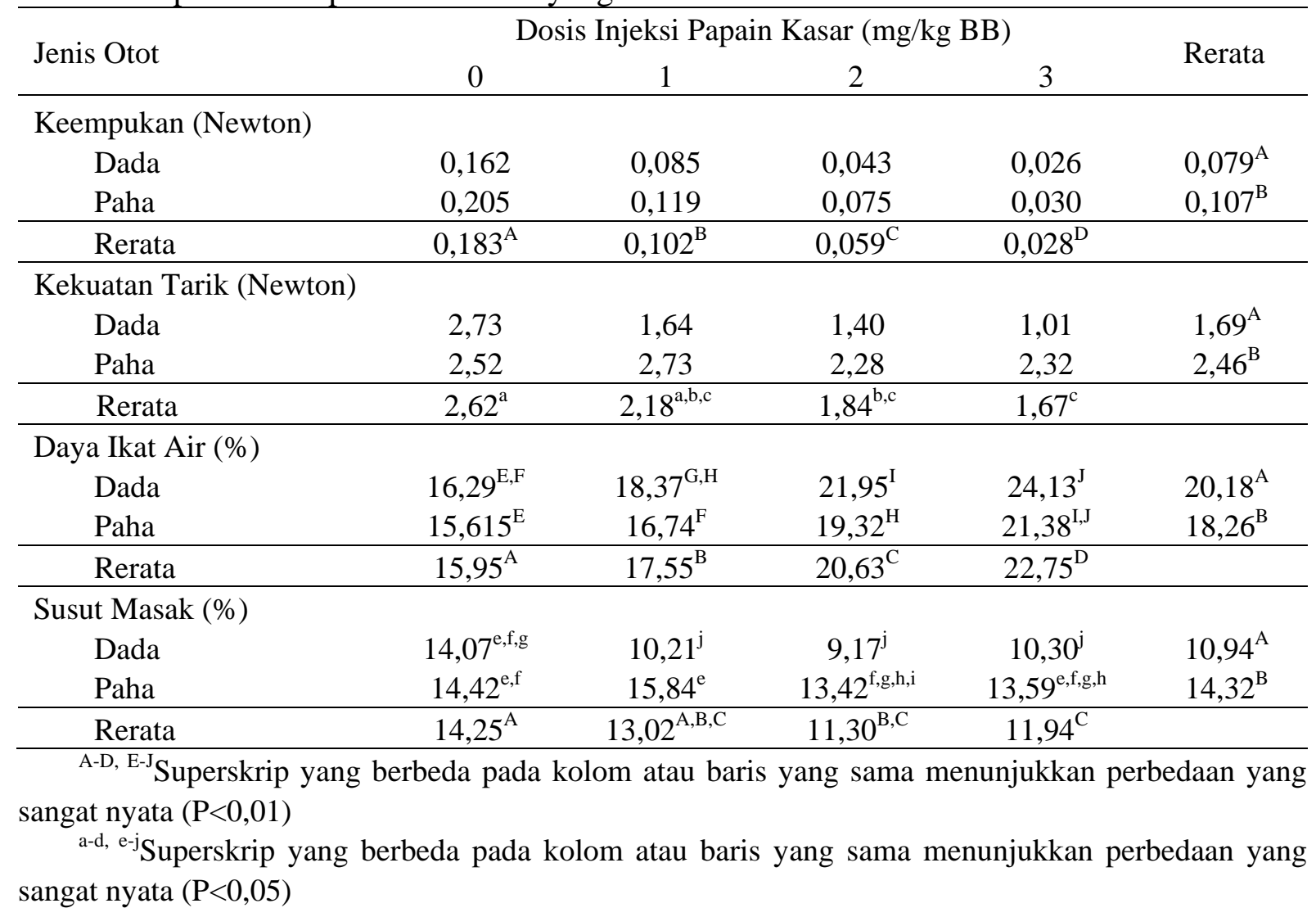

meningkatkan DIA. Daya ikat air mempengaruhi nilai susut masak daging, yaitu peningkatan DIA akan diikuti dengan turunnya persentase susut masak (Yanti et al., 2008).

Proses hidrolisis kolagen merupakan penyebab utama keempukan daging pada pemberian papain secara antemortem (Brooks et al., 1985), ini ditunjukan dengan semakin naik dosis papain daging semakin empuk, karena keempukan daging merupakan deteksi untuk hidrolisis kolagen. Kekuatan tarik menunjukan hidrolisis pada protein jaringan ikat miofibril (Soeparno,
2005). Kekuatan tarik nampak berbeda dengan kontrol pada dosis 2 dan $3 \mathrm{mg} / \mathrm{kg}$ $\mathrm{BB}$, ini menunjukan bahwa hidrolisis protein miofibril memerlukan dosis yang tertentu. Kecepatan hidrolisis enzim terhadap substrat ditentukan oleh konsentrasi enzim, sehingga bertambahnya konsentrasi enzim dapat meningkatkan kecepatan hidrolisis substrat (Nuhriawangsa, 2004a; Astutiamin's, 2009). Susut masak mengalami penurunan pada dosis 2 dan 3 mg/kg BB dibanding kontrol, hal ini disebabkan karena hirolisis protein kolagen yang lebih tinggi dibanding miofibril, sehingga sifat pengikatan protein 
terhadap air lebih kuat sehingga dapat menurunkan nilai susut masak daging.

Daging dada mempunyai nilai keempukan dan daya tarik lebih rendah dibanding daging paha, sehingga daging dada lebih empuk dibanding daging paha. Otot yang aktif menghasilkan jaringan protein kolagen lebih banyak, sehingga daging lebih alot dibanding otot yang kurang aktif (Shackelford et al., 1995). Perbedaan DIA menurut Ockerman (1996) dipengaruhi oleh kandungan protein daging, kandungan protein daging yang tinggi akan diikuti dengan semakin tingginya daya mengikat air. Kandungan protein dalam dada lebih tinggi dibandingkan paha (Hayat, 2010), sehingga protein daging dada lebih banyak mempunyai kesempatan untuk mengikat air. Hal ini pula yang berpengaruh terhadap susut masak, karena kandungan protein daging yang lebih tinggi akan mengikat air lebih kuat, sehingga ketika pemasakan air yang keluar pada daging dada lebih sedikit dibanding paha. Soeparno (2005) bahwa semakin kecil nilai prosentase susut masak semakin baik kualitasnya, karena jumlah nutrien yang keluar lebih sedikit.

Terdapat interaksi antara dosis injeksi papain dengan jenis otot terhadap DIA dan susut masak daging. Otot dada dengan penambahan dosis papain $2 \mathrm{mg} / \mathrm{kg}$ BB dan otot paha dengan penambahan dosis papain $3 \mathrm{mg} / \mathrm{kg}$ BB memberikan perbedaan sangat nyata terhadap DIA. Jumlah jaringan ikat yang menyusun masing-masing otot (substrat) akan mempengaruhi DIA karena fungsi otot yang berbeda dengan adanya hidrolisis oleh papain (enzim). Konsentrasi substrat mempengaruhi konsentrasi enzim (Nelson dan Cox, 2000). Daging dada pada dosis papain $2 \mathrm{mg} / \mathrm{kg}$ BB sudah terjadi hidrolisis protein oleh enzim dan daging paha pada dosis $3 \mathrm{mg} / \mathrm{kg} \mathrm{BB}$. Hidrolisis tersebut dapat melonggarkan susunan mikro struktur daging dengan terhidrolisisnya protein jaringan ikat daging menjadi fragmen yang lebih pendek (Istrati et al., 2012). Fragmen protein tersebut memberikan ruang bagi protein yang bersifat suka air untuk mengikat air (Soeparno,
2005), sehingga nilai DIA daging dada lebih tinggi. Selanjutnya dinyatakan pula pada kondisi ini jika dilakukan pemanasan dapat menyebabkan terbentuknya emulsi cairan daging dengan lemak, sehingga terjadi eksudasi cairan daging yang berakibat pada perubahan nilai susut masak daging, sehingga daging paha mempunyai susut lemak lebih tinggi, karena mengandung lebih banyak lemak.

Secara kualitas fisik dosis $3 \mathrm{mg} / \mathrm{kg}$ BB dan daging dada mempunyai kualitas baik, hal ini ditunjukan dengan rendahnya nilai keempukan dan tekstur dan juga tingginya DIA.

\section{Kualitas Organoleptik dan Hedonik}

Hasil perhitungan kualitas organoleptik dan hedonik daging ayam petelur afkir dengan dosis injeksi papain kasar 0, 1, 2 dan $3 \mathrm{mg} / \mathrm{kg}$ BB pada jenis otot dada dan paha disajikan pada Tabel 2.

Penambahan papain dapat meningkatkan kesan keempukan dan tekstur daging dibanding kontrol. Jumlah enzim semakin meningkat, maka semakin banyak substrat yang diubah menjadi produk (Lehninger, 1994). Protease dapat menghidrolisis ikatan kolagen daging pada otot, sehingga menyebabkan hilangnya ikatan antar serat dan juga pemecahan serat menjadi fragmen yang lebih pendek, menjadikan sifat serat otot lebih mudah terpisah sehingga daging semakin empuk (Ha et al., 2012). Selain itu pada saat relaksasi otot pasca penyembelihan protease menyebabkan ikatan aktomiosin terhidrolisis menjadi aktin dan miosin, sehingga tekstur daging menjadi lebih lembut (Forrest et al., 1975). Kondisi terbentuknya fragmen pada mikrostruktur otot karena hidrolisis protease jika dilakukan pemanasan dapat menyebabkan membengkaknya mikrostruktur tersebut sehingga cairan daging dapat tereksudasi (Nuhriawangsa, 2004b), sehingga kesan juisi dapat menurun.

Kesan keempukan dan tekstur daging dada lebih baik dibanding daging paha. Kandungan kolagen mempengaruhi kealotan 
Tabel 3. Hasil Analisis Kualitas Organoleptik dan Hedonik Daging Ayam Petelur Afkir dengan Dosis Injeksi Papain Kasar pada Jenis Otot yang Berbeda

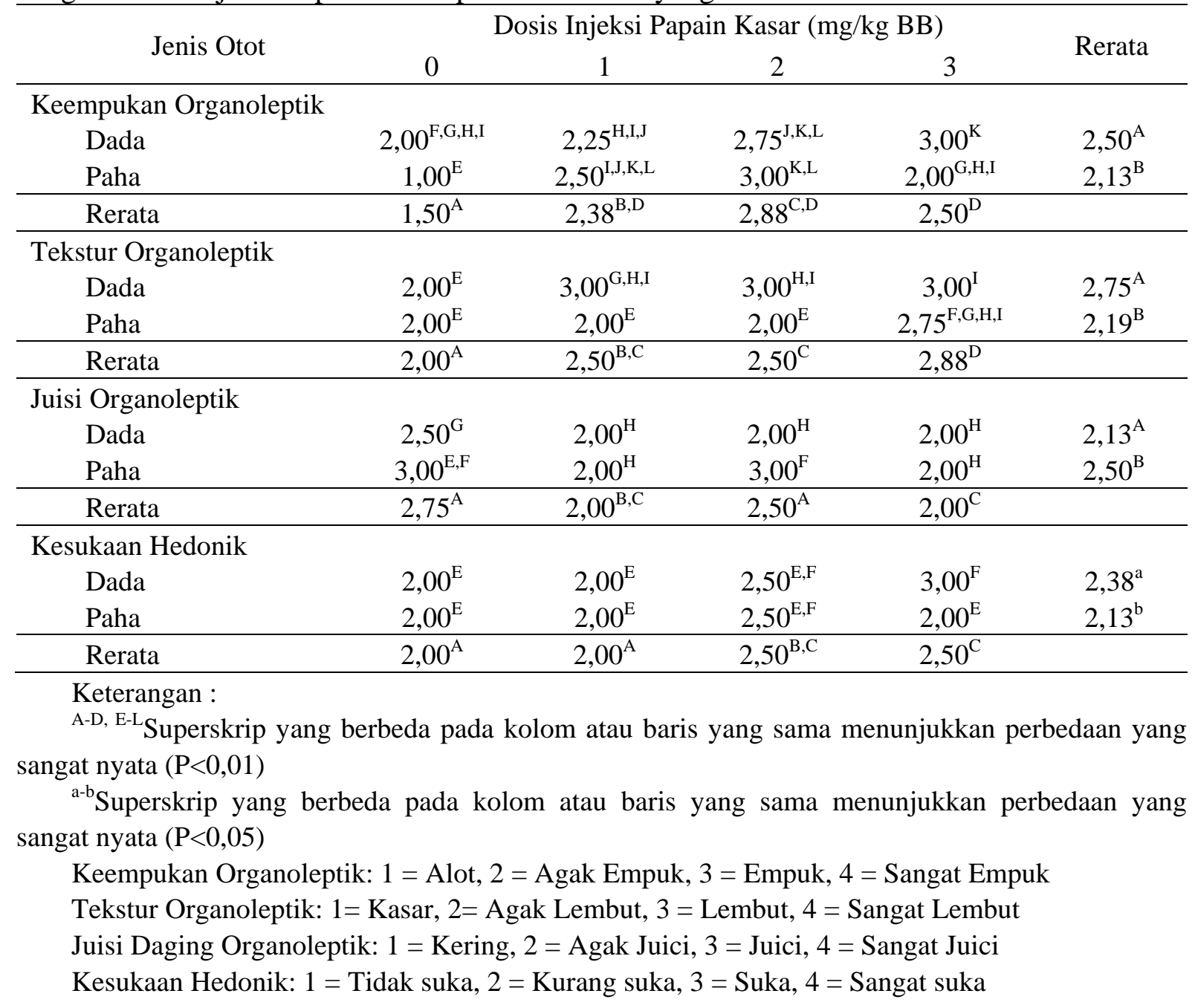

atau keempukan daging, sehingga otot yang aktif menghasilkan daging yang lebih alot dibanding otot kurang aktif (Shackelford et al., 1995). Selain itu semakin tinggi nilai keempukan daging, maka tekstur daging semakin halus (Soeparno, 2005). Daging paha mempunyai kandungan lemak lebih tinggi dibanding daging dada (Judge et al., 1989). Kandungan lemak yang tinggi mengakibatkan gelatinasi pada daging paha ketika pemasakan dan saat pengunyahan jus daging keluar, sehingga terasa lebih juisi.

Terdapat interaksi antara pemberian dosis injeksi papain dan jenis otot terhadap kesan keempukan, tekstur dan juisi daging. Jenis otot dengan kandungan protein jaringan ikat lebih banyak membutuhkan jumlah dosis papain lebih tinggi untuk memberikan kesan organoleptik yang berbeda. Menurut Supeksa (2010) semakin tinggi konsentrasi enzim dan substrat dapat mengakibatkan reaksi enzimatik berlangsung secara cepat. Pada kondisi kecepatan hidrolisis yang sama dibutuhkan jumlah enzim yang lebih banyak untuk menghidrolisis jumlah substrat yang lebih tinggi (Nelson dan Cox, 2000). Aktivitas hidrolisis protease dapat mengakibatkan perubahan kondisi mikrostruktur daging dengan terpotongnya protein jaringan ikat (Istika, 2009) dan dengan adanya pemasakan terbentuk gap cairan daging (Nuhriawangsa dan Sudiyono, 2004), sehingga terjadi perbedaan kesan organoleptik pada daging.

Kesan kesukaan hedonik menunjukan pemberian dosis $2 \mathrm{mg} / \mathrm{kg} \mathrm{BB}$ dan daging 
dada disukai oleh konsumen. Hal ini didukung dengan kesan keempukan dan juisi daging secara organoleptik, pada dosis tersebut kedua kesan mempunyai nilai yang disukai oleh panelis. Keempukan daging dan juisi merupakan parameter yang disukai oleh konsumen (Soeparno, 2005).

Terdapat interaksi antara dosis papain dan jenis otot terhadap tingkat kesukaan daging. Pemberian dosis $3 \mathrm{mg} / \mathrm{kg}$ BB pada daging dada dan $2 \mathrm{mg} / \mathrm{kg}$ BB pada daging paha memberikan kesan kesukaan panelis. Hal ini didukung dengan kesan keempukan dan juisi daging dengan kesukaan yang sama pada jumlah dosis papain dan bagian daging. Kondisi ini tidak sesuai dengan pendapat Nelson dan Cox (2000) yang menyatakan jumlah substrat (protein jaringan ikat) yang tinggi memerlukan jumlah enzim (papain) yang tinggi pula. Hal ini karena kesan organoleptik dan hedonik dipengaruhi oleh penilaian subyektivitas oleh panelis dengan alat indera (Kartika et al., 1988).

\section{KESIMPULAN}

Pemberian dosis injeksi papain 3 $\mathrm{mg} / \mathrm{kg}$ BB dan daging dada mempunyai kualitas fisik yang terbaik dan dosis $2 \mathrm{mg} / \mathrm{kg}$ BB dan daging dada mempunyai kualitas organoleptik yang terbaik. Kombinasi dosis $3 \mathrm{mg} / \mathrm{kg}$ BB pada daging paha dan dada mempunyai kualitas fisik terbaik dan kombinasi dosis $3 \mathrm{mg} / \mathrm{kg}$ BB pada daging dada dan $2 \mathrm{mg} / \mathrm{kg}$ BB pada daging paha mempunyai kualitas organoleptik terbaik.

\section{DAFTAR PUSTAKA}

Abustam, 2009. Sifat-Sifat Daging Segar. Website: www.sifat-sifat-daging.html. Diakses: Tanggal 08 Maret 2010.

Astutiamin's. 2009. Enzim dan Koenzim. Website: http://astutiamin.wordpress.com/. Diakses: Tanggal 16 September 2010.

Bintoro, V.P., B. Dwiloka dan A. Sofyan. 2006. Perbandingan daging ayam segar dan daging ayam bangka dengan memakai uji fisiko kimia dan mikrobiologi. J. Indon. Trop. Anim. Agric. 31(4):259-267.
Brooks, B. A, K. C. Klasing, and J. M. Regenstein. 1985. Effects of antemortem injected crude papain in chicken muscle. J. Food Sci. 50 (5): 1370-1374.

Deulgaonkar, S. U. Thorat, and N. Bhaskar, 2008. Purification, formulation and drying of papain. Int. J. Food Engin. 4(8)2008. (Abstract).

Filzahazny. 2009. Enzim. Web-site: http://filzahazny.wordpress.com. Diakses: Tanggal 18 Februari 2011.

Forrest, J. C., E. D. Aberle, H. B. Hedrick, M. D. Judge and R. A. Merkel. 1975. Principles of Meat Science. W. H. Freeman and Co. San Fransisco.

Ha, M., A. E. A. Bekhit, A. Carne, and D. L. Hopkins, 2012. Characterisation of commercial papain, bromelain, actinidin and zingibain protease preparations and their activities toward meat proteins. Food Chemist. 134(1):95-105.

Hanafiah, K. 2004. Rancangan Percobaan Teori dan Aplikasi. Raja Grafindo Persada. Jakarta.

Hayat, F. 2010. Kiat Memilih Ayam, yang Besar Belum Tentu Baik. Web-site: http://webcache.googleusercontent.com. Diakses: Tanggal 12 Januari 2010.

Huffman, D.L, A.Z. Palmer, J.W. Carpenter, D.D. Hargrove, and M. Koger. 1967. Effect of breeding, level of feeding and antemortem injection of papain on the tenderness of weanling calves. J. Anim. Sci. 26:290-293.

Istika, D. 2009. Pemanfaatan Enzim Bromelin pada Limbah Kulit Nanas (Ananas comosus (L.) Merr) dalam Pengempukan Daging. Skripsi. Jurusan Biologi. Fakultas Matematika dan Ilmu Lingkungan Pengetahuan Alam. Universitas Sebelas Maret. Surakarta.

Istrati, D., C. Vizireanu, and R. Dinica, 2012. Influence of post - mortem treatment with proteolytic enzymes on tenderness of beef muscle. J. Agroalimentary Proces. Tech. 18(1):70-75.

Judge, M. D., E. D. Aberle, J.C. Forrest, H. B. Hedrick and R. A. Merkel. 1989. Principles of Meat Scince. 2nd ed. Kendal/ Hunt Publishing Co., Dubuque. Iowa. 
Junaidi, W. 2009. Peternakan Ayam Ras Petelur. Web-site: http://wawan-junaidi.blogspot. com. Diakses: Tanggal 18 Desember 2010.

Kang, C. K., William D.W., and Eldon E. W. 1974. Tenderization of meat with proteolytic enzymes. In: Chicago, United State Patents number 3,818,106. Kartika, B., Hastuti P. dan Supartono, W. 1988. Pedoman Uji Inderawi Bahan Pangan. Pusat Antar Universitas Pangan dan Gizi UGM. Yogyakarta.

Lawrie, R. A. 2003. Meat Science. Penerjemah: Aminudin Parakasi. UI-Press. Jakarta.

Lehninger, A.L., 1994. Principles of Biochemistry. Penerjemah: M. Thenawijaya. Penerbit Erlangga. Surabaya.

Murtini, E.S, dan Qomarudin. 2003. Pengempukan daging dengan enzim protease tanaman biduri (Calotropis gigantea). J. Teknologi dan Industri Pangan. 14(3):266-268.

Nelson, D. L., and M. M. Cox. 2000. Lehninger Principles of Biochemistry. 3rd ed. Worth Pub., New York.

Nuhriawangsa, 1994. Komposisi Kimia Daging Dada dan Non Dada pada Karkas Ayam Broiler Jantan dan Betina Umur Enam Minggu. Skripsi. Fakultas Peternakan, Universitas Gadjah Mada, Yogyakarta.

Nuhriawangsa, A.M.P. 1999. Pengantar Ilmu Ternak Dalam Pandangan Islam: Suatu Tinjauan Tentang Fiqih Ternak. Program Studi Produksi Ternak, Fakultas Pertanian, Universitas Sebelas Maret, Surakarta.

Nuhriawangsa, A. M. P., 2004a. Pengaruh Presentase Daging Buah Pepaya dan Pemanggangan terhadap Kualitas Daging itik Afkir. Sains Peternakan, 1: 32-41.

Nuhriawangsa, A. M. P., 2004b. Pengaruh Waktu dan Lama Pemanggangan terhadap Kualitas Daging Itik Afkir. Jurnal Pengembangan Peternakan Tropis UNDIP. Edisi Khusus Nopember. Hal: 122-127.

Nuhriawangsa, A. M. P. dan Sudiyono, 2004. Pengaruh Waktu dan Lama Pemanggangan terhadap Kualitas Organoleptik Daging Itik Afkir. Sains Peternakan. Vol. 1: 90-98.
Ockerman, H. W. 1996. Chemistry of Meat Tissue. Department of Animal Sciences. The Ohio State University and The Ohio Agricultural Research and Development Center.

Perdana, J., M. B. Fox, M. A. I. Schutyser, and R. M. Boom, 2012. Enzyme inactivation kinetics: Coupled effects of temperature and moisture content. Food Chemist. 133(1): 116-123.

Person, A.M. and T.R. Dutson. 1994. Quality Attributes and Their Measrement in Meat, Poultry and Fish Product. Blakie Academic and Profesional. London.

Rukmana, R. $1995 . \quad$ Pepaya. Kanisius. Yogyakarta.

Salman dan Fifi, H. 2009. Pengembangan Formulasi Krim Papain dari Carica Papaya L. Sebagai Keratoderm Alamiah. Portal Penelitian. Universitas Andalas. Padang.

Shackelford, S. D., M. Koohmaraie, and T. L. Wheeler. 1995. Effects of slaughter age on meat tenderness and USDA carcass maturity scores of beef females. J. Anim. Sci. 73:3304 - 3309.

Soeparno, 2005. Ilmu dan Teknologi Daging. Cetakan keempat. Gadjah Mada University Press. Yogyakarta.

Supeksa, K. 2010. Metabolisme. Web-site: http://supeksa.wordpress.com. Diakses: Tanggal 15 Januari 2011.

Sutaryo, Nurwantoro, Sri Mulyani, dan Bhakti Etza Setiani, 2006. Kadar kolesterol, keempukan dan tingkat kesukaan chicken nugget dari berbagai bagian karkas broiler. J. Protein. Fakultas Peternakan. Universitas Diponegoro. Semarang. 13(1):51-55.

Tambunan, R. D. 2009. Keempukan Daging dan Faktor-Faktor yang Mempengaruhi. Balai Pengkajian Teknologi Pertanian. Lampung.

Yanti, H., Hidayati, dan Elfawati. 2008. Kualitas daging sapi dengan kemasan plastik pe (polyethylen) dan plastik pp (polypropylen) di pasar arengka kota pekanbaru. J. Peternakan. Fakultas Pertanian dan Peternakan. Universitas Islam Negeri Sultan Syarif Kasim. Pekanbaru. 5 (1): (22-27). 